\title{
BIOLOGICAL ACTION OF CHLOROFORM AND MONOCHIOROACETIC ACID DRINKING WATER ON THE ORGANISM OF THE EXPERIMENTAL AMIMAIS
}

Prokopov V.O., Tomashevska L.A., Lipovetska O.B., Kulish T.V., Kravchun T.Ye., Tsytsyruk V.S.

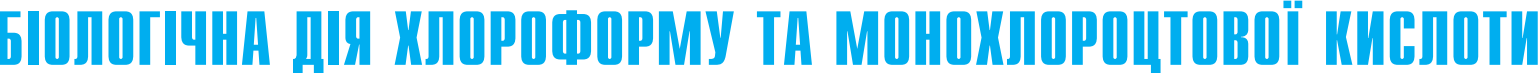 3 ПИТНОю ВодоюО НА ОРГАНІЗМ ПІДДОСлПДНИК ТВАРИН}



УДК 614.777:628.166:546.121

Ключові слова: санітарнотоксикологічний експеримент, піддослідні тварини, біологічна дія, хлорорганічні сполуки, хлороформ, монохлороцтова кислота, креатинін, аспартатамінотрансфераза, аланінамінотрансфераза, лужна фосфатаза. а даними літератури та власних досліджень [1-4], одним із чинників, що впливають на формування неінфекційної захворюваності населення, $€$ хлорована питна вода, забруднена токсичними хлорорганічними сполуками (XOC). Ці речовини за умови застосування застарілої традиційної технології водопідготовки за участі хлору на очисних спорудах річкових водопроводів практично не видаляються та транзитом надходять у питну воду міських водопровідних мереж.

Найбільшу групу ХOC складають леткі тригалогенметани (ТГМ): хлороформ (ХФ), чотирихлористий вуглець, трихлоретилен, тетрахлоретилен, бромдихлорметан, дихлорбромметан, бромоформ, дихлоретан. Разом з ними утворюються й нелеткі галогеноцтові кислоти (ГОК), пріоритетними з яких є монохлороцтова (МХОК), дихлороцтова, трихлороцтова, монобромоцтова, дибромоцтова, трибромоцтова, бромхлороцтова, дихлорбромоцтова та дибромхлороцтова кислоти. За вмістом у хлорованій питній воді ГОК посідають друге місце після ТГМ $[4,5]$.

Більшість ідентифікованих у воді XOC має експериментально встановлену високу токсичність, канцерогенність та мутагенну активність. Численні експериментальні дослідження ізольованого впливу летких ХОС вказують на токсичне ураження печінки, нирок, серця тощо. Високі рівні ТГМ можуть також призвести до пошкодження клітин головного мозку, нервової системи, нирок, ока та репродуктивної системи $[1-4,6]$.
БИОЛОГИЧЕСКОЕ ДЕЙСТВИЕ ХЛОРОФОРМА И МОНОХЛОРУКСУСНОЙ КИСЛОТЫ С ПИТЬЕВОЙ ВОДОЙ НА ОРГАНИЗМ ПОДОПЫТНЫХ ЖИВОТНЫХ Прокопов В.А., Томашевская Л.А., Липовецкая Е.Б., Кулиш Т.В. Кравчун Т.Е., Цицирук В.C.

ГУ «Институт общественного здоровья им. А.Н. Марзеева НАМН Украины», Г. Киев

Цель работы - определение особенностей биологического действия хлороформа и монохлоруксусной кислоты с питьевой водой на организм экспериментальных животных по биохимическим показателям

\section{Материалы и методы исследования.}

Проведен 6-тимесячный санитарно-токсикологический эксперимент с использованием 10 групп белых беспородных крыс: 1 - контрольная (получали артезианскую воду), 6 подопытных групп употребляли питьевую воду с содержанием хлороформа, монохлоруксусной кислоты и их комбинацией на уровне 3 и 5 ПДК соответственно, 3 подопытные группы употребляли питьевую воду с нормативным содержанием изолированных веществ и их комбинации. Функциональное состояние организма животных оценивали по изменению содержания креатинина, активности аминотрансфераз и щелочной фосфатазы в сыворотке и плазме крови.

Основные результаты. Установлено, что употребление питьевой воды с содержанием хлоро- форма (ХФ) и монохлоруксусной кислоты (МХУК) на уровне 1 ПДК как отдельных веществ, так и их комбинации не вызывало достоверных изменений в исследуемых биохимических показателях подопытных животных. Выявлена дозо-временная зависимость изменений биохимических показателей, особенно в группах животных, употреблявших питьевую воду с содержанием ХФ на уровне 3 и 5 ПДК и комбинацией ХФ и МХУК (3 и 5 ПДК). Показано, что изменения биохимических показателей при употреблении питьевой воды с комбинацией ХФ и МХУК происходят в первую очередь за счет токсического действия именно хлороформа.

Токсическое воздействие ХФ и МХУК в сверхнормативных концентрациях вызывает изменения метаболических процессов в организме животных, проявляется достоверными изменениями биохимических показателей крови, а с увеличением времени воздействия может приводить к возникновению патологических процессов в чувствительных к действию ХОС органах - печени, почках, сердце и т.д.

Ключевые слова: санитарно-токсикологический эксперимент, подопытные животные, биологическое действие, хлорорганические соединения, хлороформ, монохлоруксусная кислота, креатинин, аспартатаминотрансфераза, аланинаминотрансфераза, щелочная фосфатаза.

\footnotetext{
() Прокопов В.О., Томашевська Л.А., Липовецька О.Б., Куліш Т.в., Кравчун Т.Є., Цицирук В.С. СТАТТЯ, 2017.
} 
Наукових даних щодо дії нелетких ГОК на організм тварин існує значно менше, але усі вони визначають, що основні механізми впливу та органи-мішені $€$ спільними 3 леткими ТГМ [7].

Нині практично відсутні роботи з вивчення комбінованої дії пріоритетних сполук класів ТГМ та ГОК на організм тварин з питною водою, що не дозволяє оцінити внесок кожної з них окремо та сумісно у токсичність хлорованої питної води як небезпечного фактора ризику виникнення неінфекційної захворюваності населення. Адже при споживанні хлорованої питної води до організму надходять ХОС обох класів з однаковою лімітуючою токсикологічною ознакою шкідливості, тому можна припустити, що їхня сумісна біологічна дія може бути сильнішою, ніж кожної речовини, окремо взятої.

Мета роботи - визначення особливостей біологічної дії хлороформу та монохлороцтової кислоти з питною водою на організм експериментальних тварин за біохімічними показниками.

Матеріали та методи дослідження. Нашими дослідженнями хлорованої питної води 3 централізованих систем водопостачання на вміст летких та нелетких ХOC встановлено постійну присутність у ній хлороформу та монохлороцтової кислоти, рівні яких залежать від типу використаних на водопроводах хлорагентів, їхніх доз тощо [8, 9].

Для досягнення поставленої мети було проведено 6-тимісячний санітарно-токсикологічний експеримент з використанням білих безпородних

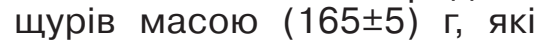
утримувались на стандартному раціоні віварію та вільному доступі до води та їжі. Для створення модельних водних розчинів використовували питну воду із артезіанської свердловини, в яку додавали хлороформ та монохлороцтову кислоту у заданих концентраціях та комбінаціях. Вміст їх у модельних розчинах контролювали на газовому хроматографі «Кристаллюкс 4000М».

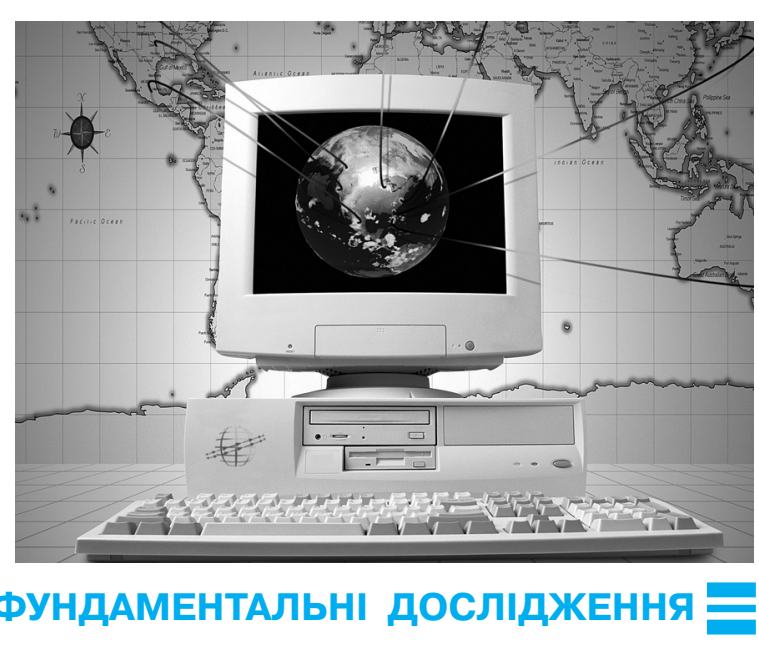

Тварини (по 8 голів у групі) були розподілені на 10 груп: 1 - контрольна (отримувала артезіанську воду), 6 дослідних груп споживали питну воду з вмістом хлороформу, MXOK та їхні комбінації на рівні кожної з них 3 та 5 ГДК, 3 дослідні групи споживали питну воду з цими ж речовинами на рівні гігієнічного нормативу (1 ГДК). ГДК хлороформу для водопровідної питної води становить 60 мкг/дм ${ }^{3}$ (відповідно до ДСанПіН 2.2.4-171-10), а монохлороцтової кислоти 20 мкг/дм ${ }^{3}$ (рекомендований норматив ВОО3) [7].

Експериментальні дослідження проводилися згідно 3

чинними нормативними документами [10]. Для оцінки функціонального стану організму тварин (функцій печінки та нирок) було обрано відповідні біохімічні показники: вміст креатиніну, активність амінотрансфераз та лужної фосфатази у сироватці та плазмі крови.

Забір матеріалу проводився на 30, 60, 120 та 180 добі експерименту. Дослідження проводили на біохімічному аналізаторі «Stat Fax-1904» за стандартними загальноприйнятими методами [11]. Статистичну обробку отриманих даних здійснювали 3 використанням методів статистичної обробки результа-

Таблиця 1

Вміст аспартатамінотрансферази (АCT) та аланінамінотрансферази (АЛТ) у сироватці крови щурів (M土m, n=5, ммоль/л)

\begin{tabular}{|c|c|c|c|c|}
\hline \multirow{2}{*}{ Група тварин } & \multicolumn{4}{|c|}{ Період дії фактора } \\
\hline & 30 діб & 60 діб & 120 діб & 180 діб \\
\hline \multicolumn{5}{|c|}{ Вміст аспартатамінотрансферази } \\
\hline Контрольна & $194,78 \pm 7,53$ & $151,23 \pm 12,12$ & $166,48 \pm 8,66$ & $173,83 \pm 8,30$ \\
\hline 1 (З ГДК ХФ) & $187,90 \pm 6,52$ & $149,40 \pm 19,02$ & $142,23 \pm 7,65^{\star}$ & $147,63 \pm 10,50$ * \\
\hline 2 (5 ГДК ХФ) & $186,46 \pm 5,68$ & $144,43 \pm 15,30$ & $152,78 \pm 7,33$ & $146,50 \pm 7,43^{*}$ \\
\hline 3 (3 ГДК МХОК) & $189,08 \pm 18,40$ & $136,29 \pm 8,03$ & $159,85 \pm 10,71$ & $165,65 \pm 10,62$ \\
\hline $4(5$ Г & $155,93 \pm 6,0^{*}$ & $125,38 \pm 7,59$ & $148,55 \pm 10,1$ & $172,53 \pm 18,56$ \\
\hline DK) & $147,70 \pm 4,19^{\star}$ & $114,50 \pm 5,80^{*}$ & $142,23 \pm 4,56^{\star}$ & $146,03 \pm 5,70^{*}$ \\
\hline $\begin{array}{l}6(5 \\
X Ф+ \\
\end{array}$ & $124,60 \pm 1,65^{\star}$ & $125,35 \pm 14,15$ & $146,75 \pm 9,12$ & $145,10 \pm 6,70^{*}$ \\
\hline \multicolumn{5}{|c|}{ Вміст аланінамінотрансферази } \\
\hline Контрольна & $65,88 \pm 4,82$ & $48,68 \pm 7,45$ & $54,38 \pm 5,48$ & $53,58 \pm 6,69$ \\
\hline 1 (З ГДК ХФ) & $68,90 \pm 2,52$ & $53,43 \pm 4,24$ & $57,15 \pm 4,62$ & $54,80 \pm 4,36$ \\
\hline 2 (5 ГДК ХФ) & $69,46 \pm 7,68$ & $50,50 \pm 3,87$ & $56,93 \pm 4,76$ & $54,95 \pm 8,08$ \\
\hline 3 (З ГДК МХОК) & $53,98 \pm 5,23$ & $50,33 \pm 11,46$ & $68,63 \pm 4,62$ & $66,33 \pm 2,97$ \\
\hline 4 (5 ГДК МХОК) & $57,58 \pm 10,30$ & $47,73 \pm 0,38$ & $57,30 \pm 10,62$ & $60,88 \pm 9,99$ \\
\hline $\begin{array}{l}5 \text { (3 ГДК } \\
\text { ХФ+МХОК) }\end{array}$ & $65,05 \pm 11,20$ & $47,73 \pm 11,0$ & $61,55 \pm 4,13$ & 12,24 \\
\hline $\begin{array}{l}6 \text { (5 ГДК } \\
\text { ХФ+МХОК) }\end{array}$ & $80,30 \pm 5,0^{*}$ & $47,08 \pm 4,62$ & $55,15 \pm 5,63$ & 52 \\
\hline
\end{tabular}

Примітка до таблиць 1 і 2: * - відмінності достовірні при порівнянні з контрольною групою $(p<0,05)$. 
поступовим зниженням показника АСТ у сироватці крови тварин 1-ї та 2-ї груп, що стало достовірним за 120 діб та тривало до кінця експерименту (група 1). У свою чергу, ізольована дія МХOK на рівні 5 ГДК (група 4) проявлялася зниженням рівня АСТ вже за 30 днів від початку експерименту, але у подальшому, хоча й зберігалася тенденція до зниження, різниця з контрольною групою була недостовірною.

Споживання тваринами 5-ї та 6-ї груп питної води з комбінацією двох пріоритетних ХOC на рівні кожної з них 3 та 5 ГДК призвело до зниження показника АСТ практично 3 початку експерименту. Вже 3 30-ї доби спостереження рівень АСТ у сироватці крови тварин цих груп був достовірно нижчим за контроль та зберігав цю тенденцію до кінця експерименту.

Рівень АЛТ у сироватці крови в усіх групах тварин суттєво не відрізнявся від показників контрольної групи. ваних речовин на рів 5 ГДК. Ізольований вплив ХФ на рівні 3 та 5 ГДК проявлявся

Вміст креатиніну у плазмі крови щурів Таблиця 2 ( $\mathrm{M} \pm \mathrm{m}, \mathrm{n}=5$, ммоль/л)

\begin{tabular}{|l|c|c|c|c|}
\hline \multirow{2}{*}{ Група тварин } & \multicolumn{4}{|c|}{ Період дії фактора } \\
\cline { 2 - 5 } & 30 діб & 60 діб & 120 діб & 180 діб \\
\hline Контрольна & $0,37 \pm 0,02$ & $0,37 \pm 0,01$ & $0,44 \pm 0,14$ & $0,40 \pm 0,04$ \\
\hline 1 (3 ГДК ХФ) & $0,37 \pm 0,01$ & $0,38 \pm 0,03$ & $0,30 \pm 0,02^{*}$ & $0,33 \pm 0,01^{*}$ \\
\hline 2 (5 ГДК ХФ) & $0,35 \pm 0,03$ & $0,33 \pm 0,01^{*}$ & $0,31 \pm 0,03^{*}$ & $0,35 \pm 0,01^{*}$ \\
\hline 3 (3 ГДК МХОК) & $0,32 \pm 0,02$ & $0,31 \pm 0,01^{\star}$ & $0,43 \pm 0,08$ & $0,38 \pm 0,01$ \\
\hline 4 (5 ГДК МХОК) & $0,33 \pm 0,03$ & $0,35 \pm 0,02$ & $0,42 \pm 0,09$ & $0,39 \pm 0,02$ \\
\hline 5 (3 ГДК ХФ+МХОК) & $0,35 \pm 0,06$ & $0,33 \pm 0,01^{*}$ & $0,33 \pm 0,01^{*}$ & $0,31 \pm 0,02^{*}$ \\
\hline 6 (5 ГДК ХФ+МХОК) & $0,31 \pm 0,03$ & $0,33 \pm 0,02^{*}$ & $0,32 \pm 0,02^{*}$ & $0,31 \pm 0,02^{*}$ \\
\hline \multicolumn{5}{|c|}{ Вміст лужної фосфатази у плазмі крови щурів } \\
(М $\pm \mathbf{m , ~} \mathbf{n = 5 , ~ м м о л ь / л ) ~}$
\end{tabular}

\begin{tabular}{|l|c|c|c|c|}
\hline \multirow{2}{*}{ Група тварин } & \multicolumn{4}{|c|}{ Період дії фактора } \\
\cline { 2 - 5 } & \multicolumn{1}{|c|}{30 діб } & 60 діб & 120 діб & 180 діб \\
\hline Контрольна & $221,30 \pm 11,50$ & $215,70 \pm 12,80$ & $223,70 \pm 12,27$ & $222,70 \pm 13,50$ \\
\hline 1 (3 ГДК ХФ) & $228,50 \pm 9,52$ & $231,05 \pm 11,17$ & $228,50 \pm 8,26$ & $242,20 \pm 5,83$ \\
\hline 2 (5 ГДК ХФ) & $229,46 \pm 11,80$ & $231,80 \pm 9,12$ & $230,60 \pm 16,50$ & $238,60 \pm 7,79$ \\
\hline 3 (3 ГДК МХОК) & $227,70 \pm 6,12$ & $226,40 \pm 16,30$ & $232,20 \pm 21,74$ & $256,30 \pm 23,64^{\star}$ \\
\hline 4 (5 ГДК МХОК) & $226,90 \pm 17,90$ & $241,0 \pm 5,83$ & $232,30 \pm 11,86$ & $229,80 \pm 8,17$ \\
\hline 5 (3 ГДК ХФ+МХОК) & $230,10 \pm 7,45$ & $229,70 \pm 11,58$ & $262,20 \pm 4,94^{*}$ & $267,20 \pm 5,11^{*}$ \\
\hline 6 (5 гДК ХФ+МХОК) & $243,80 \pm 11,90$ & $242,80 \pm 14,40$ & $254,40 \pm 7,30 * *$ & $255,20 \pm 4,21^{\star *}$ \\
\hline
\end{tabular}

Примітки: * - відмінності достовірні порівняно з контрольною групою $(p<0,05) ;{ }^{* *}-p<0,1$.
Лише у 6-й групі тварин, що зазнавала поєднаної дії хлороформу та монохлороцтової кислоти на рівні кожної з них 5 ГДК, підвищення показника АЛТ після 30 діб впливу досягло достовірних значень $(p<0,05)$, але у подальшому його значення суттєво не відрізнялося від показників контрольної групи та перебувало у межах коливань фізіологічної норми для щурів.

Таке тривале зниження показника АCT у сироватці крови тварин може бути проявом токсичного ураження леткими та нелеткими хлорорганічними сполуками клітин печінки у поєднанні зі зниженням процесів їх регенерації. Зниження АСТ у групах 5 та 6 за дії комбінації ХФ та МХOK практично з початку експерименту, а також у групах 1 та 2, за дії ХФ, свідчить про більш виражений вплив на функції печінки саме хлороформу. Крім того, зниження рівня АСТ може свідчити про патологічне ураження кардіоміоцитів, особливо на фоні незначних змін рівня АЛТ у сироватці крови.

у таблиці 2 представлено результати визначення вмісту креатиніну у плазмі крови щурів. Аналіз даних таблиці свідчить, що внаслідок дії токсичних XOC на організм відзначалося зниження рівня креатиніну відносно контрольної групи в усіх дослідних групах тварин протягом експерименту.

Найбільші зміни вмісту креатиніну спостерігалися у групах 5 та 6, які зазнавали поєднаної дії хлороформу та монохлороцтової кислоти на рівні кожної 3 них 3 та 5 ГДК вже після 60 діб впливу $(p<0,05)$. Крім того, зниження рівня креатиніну визначали у тварин, що піддавались ізольованій дії хлороформу на рівні 3 ГДК зі 120-ї доби спостереження та на рівні 5 ГДК з 60-ї доби.

Ізольована дія монохлороцтової кислоти на рівень креатиніну у плазмі крови щурів групи 3 проявлялася його достовірним зниженням на 60-ту добу спостереження, а у подальшому достовірно не відрізнялася від контрольної. 
BIOLOGICAL ACTION OF CHLOROFORM AND MONOCHLOROACETIC ACID DRINKING WATER ON THE ORGANISM OF THE EXPERIMENTAL ANIMALS Prokopov V.O., Tomashevska L.A., Lipovetska O.B., Kulish T.V., Kravchun T.Ye., Tsytsyruk V.S. SI «O.M. Marzeiev Institute for Public Health, NAMSU», Kyiv

Objective. We determined the specific features of the biological action of chloroform and monochloroacetic acid with drinking water on the organism of the experimental animals according to the biochemical parameters.

Materials and methods. A 6-monthes sanitaryand-toxicological experiment was performed using 10 groups of white, mongrel rats: 1 - control (they were given artesian water), 6 experimental groups drank water with chloroform, monochloroacetic acid, and their combination at levels 3 and 5 MPC, respectively, and 3 experimental groups that consumed drinking water with a standard content of both isolated substances and their combinations. The functional state of the animal body was assessed by the change in creatinine content, aminotransferase and alkaline phosphatase activity in serum and blood plasma.

Results. Drinking water with the content of chloro- form (CF) and monochloroacetic acid (MCAA) at the level of 1 MPC of both individual substances and their combination did not cause significant changes in the biochemical indices of the experimental animals. The dose-time dependence of changes in biochemical indices was revealed especially in the groups of animals drinking water with CF content at the level of 3 and 5 MPC and a combination of CF and MCAA ( 3 and 5 MPC). When drinking water is used with a combination of CF and MCAA the changes in biochemical parameters take place primarily due to the toxic effect of chloroform.

The toxic effect of CF and MCAA in the excess concentrations causes changes in metabolic processes in the organism of animals, is manifested by the significant changes in the biochemical parameters of the blood, and, with an increase in the exposure time, can lead to the emergence of pathological processes in organs sensitive to the action of organochlorine compound (liver, kidney, heart).

\section{Keywords: sanitary-and-toxicological experiment, experimental animals, biological action, organochlorine compounds, chloroform, monochloroacetic acid, creatinine, aspartate aminotransferase, alanine aminotransferase, alkaline phosphatase.}

Таким чином, можна відзначити, що токсична дія ХФ та комбінації ХФ+МХOK на рівні кожної з них 3 та 5 ГДК на вміст креатиніну у плазмі крови достовірно проявилася вже за 2 місяці від початку експерименту та зберігала цю тенденцію до його завершення. Зниження показника креатиніну у плазмі крови тварин може свідчити про порушення метаболічних процесів, що супроводжуються глибокими розладами функцій печінки та нирок.

При вивченні ізольованого впливу хлороформу на рівень лужної фосфатази у досліджуваних концентраціях (групи 1 та 2) спостерігалося зростання ії вмісту у плазмі крови щурів відносно контрольного показника, але це підвищення не набуло достовірності протягом усього експерименту (табл. 3).

у групі 3 дія питної води 3 вмістом МХOК на рівні 3 ГДК проявлялася тенденцією до підвищення рівня лужної фосфатази у плазмі крови щурів 3 достовірним значенням показника на 180 добу проведення експерименту.

Комбінований вплив хлороформу та монохлороцтової кислоти на рівні 3 ГДК зумовив достовірне зростання рівня ЛФ у плазмі крови тва- рин 5-ї групи зі 120-го дня експерименту та зберігав цю тенденцію і у подальшому. У 6-й групі тварин, що споживала питну воду з комбінацією хлороформу та MXOK на рівні 5 ГДК, відзначалася стійка тенденція до зростання рівня лужної фосфатази $(p<0,1)$, яка за умови продовження експерименту мала б чітку різницю порівняно 3 контрольною групою.

Зростання активності лужної фосфатази може бути проявом токсичного пошкодження або деструкції гепатоцитів, що у поєднанні зі змінами інших біохімічних показників характеризує негативні зрушення функцій печінки та нирок піддослідних тварин у результаті токсичного впливу питної води, забрудненої леткими та нелеткими ХOC.

\section{Висновки}

За результатами 6-тимісячного санітарно-токсикологічного експерименту виявлено дозо-часову залежність змін біохімічних показників піддослідних тварин від впливу понаднормативних концентрацій пріоритетних летких (хлороформ) та нелетких (монохлороцтова кислота) ХОС у питній воді. Зміни рівнів досліджуваних показників (АСТ, АЛТ, креатинін, лужна фосфатаза) спостерігалися протягом усього експерименту в усіх досліджуваних групах тварин. Особливо значущими вони були у групах тварин, що споживали питну воду з вмістом ХФ на рівні 3 та 5 ГДК і комбінацією ХФ та MХOK (3 та 5 ГДК). Питна вода з вмістом лише МХOК викликала значно менші зміни досліджуваних показників. Отже, можна припустити, що зміни біохімічних показників за умови споживання питної води з комбінацією летких та нелетких ХOC відбуваються передусім за рахунок токсичної дії хлороформу.

Токсичний вплив понаднормативних концентрацій летких та нелетких XOC питної води викликає зміни метаболічних процесів в організмі тварин, що проявляється достовірними змінами біохімічних показників крови, а зі збільшенням часу впливу може призводити до виникнення патологічних процесів у чутливих до дії ХОС органах печінці, нирках, серці тощо.

ЛІТЕРАТУРА

1. Schencka K.

Sivaganesana M., Rice G. Correlations of Water Quality Parameters with Mutagenicity of Chlorinated Drinking Water Samples. Journal of Toxicology and Environmental Health. 2009. Vol. 72. № 7. P. 461-467.

\section{Bviroverst \& Ilearu № 32017}


наук. -практ. конф. (XII Марзеєвські читання). Вип. 16. Київ, 2016. C.178-180.

9. Прокопов В.О.,

Труш Є.А., Куліш Т.В.,

Соболь В.А. Утворення летких та нелетких хлорорганічних сполук при обробці природної води різними хлорокисниками. Актуальні питання гігієни та екологічної безпеки України : зб. тез доп. наук. практ. конФ. (ХІІ Марзєєвські читання). Вип. 16. Київ, 2016. C.183-186.

10. Principles and Methods for Assessing Direct Immunotoxicity Associated with Exposure to Chemicals. Geneva : WHO, 1996. 390 p.

11. Покровский А.А.

Биохимические методы исследования в клинике. М. : Медицина, 1969. 652 с.

12. Антомонов М.Ю.

Математическая обработка и анализ медико-

биологических данных. К., 2006. 558 c.

REFERENCES

1. Schencka K.,

Sivaganesana M. and Rice G. Journal of Toxicology and Environmental Health. 2009 ; $72(7)$ : 461-467.

2. Prokopov V.A. and Shushkovskaia S.V. Dovkillia ta zdorovia. 2012 ; 3 (62) : 46-51 (in Russian).

3. Chernichenko I.A., Balenko N.V. and Litvichenko O.N. Gigiena i sanitariia. 2009 ; 3 : 28-33 (in Russian).

4. Prokopov V.O. Pytna voda Ukrainy: medyko-ekolohichni ta sanitarno-hihiienichni aspekty [Drinking Water of Ukraine:

Medico-Ecological and

Sanitary-and-Hygienic

Aspects]. Kyiv : Meditsyna, 2016: 400 p. (in Ukrainian).

5. Prokopov V.A., Trush E.A., Kulish T.V. and Sobol V.A. Sravnitelnaia gigienicheskaia otsenka soderzhaniia toksicheskikh letuchikh i neletuchikh khlororganicheskikh soedineniy v vodoprovodnoy pitievoy vode [Comparative Hygienic Assessment of the Content of Toxic Volatile and Nonvolatile Organo-Chlorine Compounds in Tap Drinking Water]. In : Hihiena naselenykh mists [Hygiene of Settlements]. Kyiv ; 2015 ; 65 : 44-50 (in Russian).
6. Richardson S., Plewa M. and Wagner E. Mutation Research. 2007 ; 636 : 178-242.

7. Monochloroacetic Acid in Drinking Water: Background Document for Development of WHO Guidelines for Drinking Water Quality. Geneve : WHO ; 2004 : 17 p.

8. Prokopov V.O., Trush Ye.A., Kulish T.V. and Sobol V.A.

Doslidzhennia vplyvu okremykh faktoriv na protses utvorennia letkykh ta neletkykh

khlororhanichnykh spoluk v pytnii vodi [Study of the Impact of Separate Factors on the Process of the Formation of Volatile and Nonvolatile Compounds in Drinking Water]. In : Aktualni pytannia hihiieny ta ekolohichnoi bezpeky Ukrainy: tezy konf. [Actual Issues of Hygiene and Ecological Safety of Ukraine : Coll. Report Abs. Sci.-Pract. Conf. (The Twelfth Marzeiev's Reading]. Kyiv; 2016 : 178-180 (in Ukrainian). 9. Prokopov V.O., Trush Ye.A., Kulish T.V. and Sobol V.A. Utvorennia letkykh ta neletkykh khlororhanichnykh spoluk pry obrobtsi pryrodnoi vody riznymy khlor okysnykamy [Formation of Volatile and Non-Volatile OrganoChlorine Compounds at the Treating of Native Water with Different Oxidants]. In : Aktualni pytannia hihiieny ta ekolohichnoi bezpeky Ukrainy : tezy konf. [Actual Issues of Hygiene and Ecological Safety of Ukraine : Coll. Report Abs. Sci.-Pract. Conf. (The Twelfth Marzeiev's Reading]. Kyiv ; 2016 : 183-186 (in Ukrainian). 10. Principles and Methods for Assessing Direct Immunotoxicity Associated with Exposure to Chemicals.

Geneva : WHO; 1996 : 390 p.

11. Pokrovskiy A.A.

Biokhimicheskie metody issledovaniia v klinike [Biochemical Methods for Study in Clinic]. Moscow : Meditsina ; 1969 : 558 p. (in Russian).

12. Antomonov M.Yu.

Matematicheskaia obrabotka i analiz mediko-biologicheskikh dannykh [Mathematical Processing and Analysis of Medico-Biological Data]. Kiev ; 2006 : 558 p. (in Russian).

Надійшла до редакції 21.03.2017 питання гігієни та екологічноі безпеки України : зб. тез доп. 